\author{
Katarina Pavičić Dokoza \\ Poliklinika SUVAG, Zagreb
}

\section{Verb processing in children with developmental language disorder}

\author{
Procesiranje glagola kod djece s razvojnim \\ jezičnim poremećajem
}

\begin{abstract}
Speed, accuracy, and type of errors during word processing in children with developmental language disorder (DLD) have often been in the focus of various lexical studies. Results of these studies are uniform: children with DLD show slow and less accurate processing. Less is known about the speed and accuracy of verb processing. Therefore, the aim of this study is to explore whether there are differences in the speed and accuracy of verb processing between children with DLD and their typical developing chronological peers (TDC) and younger, language age-matched peers (TDC-y), with special attention to the type of errors produced. The participants in this pilot study were 30 children between the ages of 7;11 and 11 years. Average age of children with DLD was 10;2; TDC children 9;9; and TDC-y children were 8,1. Research procedure included stimulus word presented in auditory form, and children's task was to choose which one of the three presented pictures on computer screen represent the verb they just heard. Results showed no statistically significant differences regarding speed and accuracy between groups of participants. The difference in proportion of errors in picture selection task did not reach statistical significance when it comes to phonological mistakes, nor when it comes to semantic errors. However, the proportion of phonological errors had a tendency of highest scores in group of children with DLD, while proportion of semantic errors was highest in TDC-y. According to findings from this study, it seems important to emphasize the importance of phonological exercises parallel with exercises focused on vocabulary span in work with children with DLD. Number of exposures to the new word in children with DLD can play a significant role in speed of processing but it can also lead to overlearning affecting research outcomes. Children with DLD who participated in this study had been enrolled in speech and language therapy for several years. Future studies should, among other, also control this variable.
\end{abstract}

\begin{abstract}
SAŽETAK
Brzina, točnost i vrsta pogrešaka tijekom jezične obrade kod djece s razvojnim jezičnim poremećajima (RJP), često su bili u fokusu različitih leksičkih studija. Rezultati studija su ujednačeni: djeca s RJP-om pokazuju sporo i manje precizno procesiranje. Manje se zna o brzini i točnosti obrade glagola. Stoga je cilj ovog istraživanja istražiti - postoje li razlike u brzini i točnosti obrade glagola između djece s RJP-om-om i djece urednog jezičnog razvoja, ujednačenih po kronološkoj i receptivnoj jezičnoj dobi, s osvrtom na vrstu pogrešaka. U istraživanju je sudjelovalo tridesetak djece u dobi od 7;11 do 11;0 godina. Prosječna dob djece s RJP-om bila je 10;2 godina, starije djece urednog jezičnog razvoja 9;9 godina, a mlađe djece urednog jezičnog razvoja izjednačenih s djecom s razvojnim jezičnim poremećajem s obzirom na razinu receptivnog jezika 8;1 godina. Postupak istraživanja obuhvaćao je izgovorenu poticajnu (stimulus) riječ, a zadatak ispitanika bio je odabrati koja od tri prikazane slike na ekranu računala predstavlja glagol koji su upravo čuli. Istraživanje nije pokazalo statistički značajne razlike u pogledu brzine i točnosti između ispitanih skupina djece. Razlika u tipu pogrešaka u zadatku odabira slike nije dosegnula statističku značajnost, kada su u pitanju fonološke kao niti semantičke pogreške. Međutim, udio fonoloških pogrešaka imao je tendenciju najvećih rezultata u skupini djece s RJP-om, dok je udio semantičkih pogrešaka najveći u skupini mlađih kontrolnih ispitanika. U skladu s rezultatima ovog istraživanja, važno je naglasiti uključivanje fonoloških vježbi paralelno s vježbama usmjerenima na opseg rječnika u radu s djecom s RJP-om. Učestalost izloženosti novoj riječi kod djece s RJP-om može igrati značajnu ulogu u brzini obrade, ali i dovesti do efekta prenaučenosti, što može utjecati na rezultate istraživanja. Djeca s RJP-om - sudionici ovog istraživanja, bila su nekoliko godina uključena u logopedsku terapiju. Buduća istraživanja bi, među ostalim, također trebala kontrolirati i ovu varijablu.
\end{abstract}

Keywords: verb processing developmental language disorder

Ključne riječi: procesiranje glagola razvojni jezični poremećaj 


\section{INTRODUCTION}

Problems with lexical development occur at many children with developmental language disorders (heareafter DLD). Children with DLD can show poor naming skill caused by more general lexical difficulties despite adequate receptive vocabulary skill (Dockrell, Messer \& George, 2001). Dockrell, Messer, George, Ralli (2003) found that children with DLD produced fewer and less accurate definition of word compared to two groups of children matched with chronological age and younger, matched on the level of receptive grammar. This finding can be supporting the thesis that naming difficulties are often associated with impoverished semantic representation which leads to a retrieval problem (Nash \& Donaldson, 2005). In the other words, lexical problems may have their roots in storage or encoding stage, a theory proposed by Leonard's storage hypothesis (Leonard, 1998). On the other hand, generalised slowing hypothesis (Kail, 1994) predict that children with DLD will have a slower processing speed across a wide linguistic and non-linguistic task. However, it is still not clear what the nature of these difficulties is. There are at least three types of merit questions regarding this issue. Do children with DLD have problems with phonological properties or semantic properties of new words or both? The second question is to what extant are word learning difficulties influenced by the learning context, e.g. where their meaning must be inferred vs. context were an explicit instruction about their meaning is provided. Number of exposures to the new word in children with DLD can play a significant role in speed of processing. This stands for all children not just children with DLD. If a larger number of the underlying language processes (phonological memory, phonological analyses and syntheses, semantic/conceptual analysis, morphosyntactic) are responsible for lexical processing, disturbance of which process is the most common cause of lexical deficit? Poor phonological memory skills are often mentioned as a cause of difficulties in word learning. Evidence for this found in research show impaired performance on nonword repetition tests (Bishop at al., 1996). Poor phonological working memory skills can affect the ability to establish durable and discriminable representation of phonological form of newly learned word in long term memory. Also, research showed that children with DLD have deficits in learning and retaining new lexical items (Weismer \& Hesketh, 1996), in size and depth of their vocabularies and semantic knowledge (Brackenbury \& Pye, 2005), or problems in integration of all words properties (Bastiaanse \& Bol, 2001).

Speed of language processing in children with DLD has been studied in various contexts. Results conducted by Miller, Kail, Leonard, \& Tomblin (2001) showed that speed of processing of children with DLD are slower than of children with typical language development. Findings from different research support the fact that children learn nouns faster than they do verbs (Bornstein at. al., 2004; Genther, 2006). Research on speed of processing of verbs in children with DLD is especially interesting since verbs are more complex than nouns, and action naming has been shown to be more difficult than object naming (Sheng \& McGregor, 2010). After verb has entered children's vocabularies, learning their full meaning takes a prolonged time. There is a large volume of literature that shows that verbs are acquired later than nouns and that they tend to be more impaired in developmental language disorders (for more details see Masterson, Druks, Gallienne, 2008). Authors emphasised that motor features that have anterior anatomical substrate contribute predominantly to the conceptual representation of (concrete) verbs. Beside the anatomical features regarding verbs production, the semantic representations have also been considered to be more complex than those of nouns, i.e. the semantic organisation of verbs is considered to be shallower and matrix-like (Huttenlocher \& Lui, 1979 cited in Masterson at al., 2008). Also, verbs determine the number and type of arguments and have numerous subcategories. The earliest stages of language acquisition are bound to be affected by this variability since very early verbs such as dream, drink, eat, open are often used with different constellations of arguments. So, learning one verb does not necessarily allow generalising to another (compared to nouns), imposing a great burden on their acquisition (Gleitman, 1994, cited in Masterson at al., 2008). Verbs tend to be associated with more inflections than nouns. Although verbs are most frequent words in English their higher token frequency does not compensate for their relative difficulty. So, verbs remain disadvantaged despite being more frequent than nouns (Masterson at al., 2008).

Thompson (2003) conducted research on people with aphasia. As compared to typical subjects, agrammatic participants produced a greater proportion of one- and twoargument verbs and copulas and fewer three-argument and complement verbs. Also, a hierarchy of difficulty in verb production based on argument structure was found. The data from this study suggest that difficulties in accessing verbs for production is influenced by the verb's lexical entry. Models of lexical processing suggest that access to conceptually determined items entails a lexical search, which involves automatic activation of lexically specified material of both the target and related items (Thompson, 2003). The finding that verbs with a more complex argument structure present difficulty for production suggests that verb production deficits in agrammatic aphasic individuals are tied to problems accessing verbs with complex lexical entries.

Rothweilr, Chila, Clahsen (2011) came to a similar conclusion regarding the monolingual and the bilingual children with DLD. They all had corrected (present vs. preterit) tense marking and produced syntactically complex sentences such as embedded clauses and wh-questions, but were limited in reliably producing correct agreement-marked verb forms.

Regarding all this, it could be presumed that verbs processing will be slower in children with DLD.

\section{RESEARCH GOAL}

Research exploring on-line verb's accuracy, reaction time and error analyses of children with DLD is sparse. According to author knowledge, study measuring accuracy, reaction time and error analysis of verb stimuli is not conducted in Croatian-speaking children with DLD.

The research was conducted to explore accuracy, reaction time and error analyses in lexical processing task of 
children with developmental language disorder (DLD) matched by two typical groups - chronologically agematched peers (TDC) and younger, language age-matched peers (TDC-y).

According to the research goal, three research hypotheses were derived:

1) children with DLD will be less accurate in choosing the target verb than TDC and TDC-y children;

2) children with DLD will have a longer reaction time compared to TDC and TDC-y children;

3) error analyses will show different findings for the group of DLD children compared to the both groups of children with typical language development.

\section{METHOD}

\section{Participants}

The participants in this pilot study were 30 children between 7;11 and 11 years. The average age of children with DLD was 10;2, average age of TDC children matched by chronological age was 9;9, and of younger children matched on receptive language score (TDC-y) was 8;1. Groups consisted of 10 children, i.e. 10 children with DLD and 20 children with typical language development (10 age-matched and 10 matched by receptive language score). Languagematched controls were selected by results on PPVT-III-HR (Dunn et al., 2009) and TROG-2:HR (Bishop, Kuvač Kraljević, Hržica, Kovačević, Kologranić Belić, 2014).

All children spoke Croatian language at home. DLD children were enrolled in SLT therapy in SUVAG Polyclinic (SUVAG Elementary school). Selection criteria were results on standardised vocabulary and grammar tests more than 1,5 SD less than average, nonverbal abilities within the normal range (measured with Wechsler Intelligence Scale for Children (WISC) and no history of hearing or neurological disorders. DLD children were enrolled in the study according to previous clinical assessment of their SLTs. TDC were selected from mainstream elementary school according to the selection made by their teacher. Inclusion criteria were normal hearing status, no history of speech and language difficulties, no history of any neurological disorders, no other significant special needs, or poor school attendance. Control children were deemed to be making typical progress by their teachers. Groups were matched according to group of children not subject per subject.

\section{Material}

Experiment was designed as a picture selection task, using E-prime 2.0 software. The stimuli were black and white pictures of 36 verbs. The research procedure included a stimulus verb presented in auditory form, and children's task was to choose which one of the three presented pictures on computer screen represents the verb they had just heard. One picture represented the target verb, and the other two were chosen on basis of semantic and phonological similarity to target verb (e.g., target word was tući/beat, phonological distractor was word vucildrag and semantical distractor was ljubiti/love). Stimulus used in this study were verbs whose concepts were expected to be within participants' vocabularies. Verbs were chosen by the author of the study in cooperation with children's teacher and SLT. During the preparation of study Croatian Lexical Database (Kuvač Kraljević, J., Olujić, M. (2018) or similar sources of relevant psycholinguistic features of words did not exist. Because of that only frequency of verbs, subjectively assessed by SLTs and teacher, was taken into consideration.

Target words were presented to children in random order, and ordering of picture types (i.e. target verb, phonologically and semantically distracted verb) was random at each trial. Two sets were presented as an exercise sets before target sets.

\section{Procedure}

Children were tested individually in a SLT room. Naming latencies were measured as time from the appearance of the stimuli to the pressing of a key on a keyboard.

Accuracy and reaction time (RT) were determined for each group of children. For the analysis of RT, incorrect answers were eliminated. Trials with RT bellow $300 \mathrm{~ms}$ and those above $3000 \mathrm{~ms}$ were considered outliers, and were excluded from analysis (Linck, Kroll \& Sunderman, 2009). After this trimming, RTs that were +/- 2SD from each child's RT were also excluded from further analysis, following usual procedure for this type of research (e.g. Windsor \& Kohnert, 2004).

\section{RESULTS AND DISCUSSION}

\section{Accuracy}

Since distributions of correct responses for each group were skewed, median and interquartile range were used as measures of central tendency and variability, and comparison was carried out using a nonparametric statistical test.

Table 1. Percentage of correct responses in each group of participants

\begin{tabular}{|l|c|c|}
\hline & Median & (IQR) \\
\hline DLD children & $80.0 \%$ & $(70,0 \%-80,0 \%)$ \\
\hline Age matches & $80.0 \%$ & $(77,5 \%-82,5 \%)$ \\
\hline $\begin{array}{l}\text { Receptive } \\
\text { language matches }\end{array}$ & $80.0 \%$ & $(77,5 \%-90,0 \%)$ \\
\hline
\end{tabular}

Kruskal-Wallis test did not indicate statistically significant difference between the groups in percentage of correct responses $\left(\chi^{2}=2,43 ; \mathrm{df}=2 ; \mathrm{p}=0,296\right)$.

Although there were no statistically significant differences regarding the accuracy in all groups, TDL-y compared to other two groups of children.children showed larger variability (interquartile range). Findings from this 
research don't corroborate previous research regarding verb processing. This is in line with some other studies. For example, Bastianse and Bol (2001) suggests that reduced diversity of verbs in spontaneous speech is not a direct reflection of a problem in verb retrieval. However, high average results and range in all three groups of participants suggest that verbs were well known to participants. This might have had influence on the similar performance of three groups. Linking acoustic or printed forms of words and their meaning is a cognitive process (Auer, 2009) and accuracy of word recognition is affected by psycholinguistic characteristics of the words. Soares, Costa, Machado, Comesaña, Oliveira (2017) emphasised that these characteristics refer to conceptual, and linguistic features, as well as frequency. During the time of structuring the stimulus material for study databases of psycholinguistic features of words were not available for Croatian, such as Croatian Lexical Databese. As its authors state, the lack of normative data for all (psycho)linguistic properties of words in Croatian was a primary motivation for its development (Kuvač Kraljević, Olujić, 2018). Future research in Croatian language should rely on available sources of psycholinguistic features in Croatian and take into consideration psycholinguistic features of verbs to be able to eliminate effect of highly automated verbs and to avoid ceiling effect in attempt to discuss accuracy and RT of verbs processing in DLD children.

\section{Reaction time}

Since distributions of RT were skewed, median and interquartile range were used as measures of central tendency and variability, and comparison was carried out using nonparametric statistical test.

Table 2. Reaction time in each group of participants

\begin{tabular}{|l|c|c|}
\hline & Median & (IQR) \\
\hline DLD children & 1801,7 & $(1240,9-2249,6)$ \\
\hline Age matches & 1677,1 & $(1410,3-2094,8)$ \\
\hline $\begin{array}{l}\text { Receptive } \\
\text { language matches }\end{array}$ & 1779,4 & $(1303,7-2037,2)$ \\
\hline
\end{tabular}

Kruskal-Wallis test did not indicate statistically significant difference between the groups in RT $\left(\chi^{2}=0,15\right.$; $\mathrm{df}=2 ; \mathrm{p}=0,929)$.

Children with DLD had a tendency to longer RT than controls groups, although the difference between groups did not reach statistical significance. Variability was also highest in group of children with DLD.

Recent studies suggest that individual differences in language processing speed play an important role in explaining the speed with which children acquire language (for more information see Peter at. al., 2019). Although in this study no statistical difference was found, it has to be taken into consideration that the number of participants per group was small. Clear tendencies showing slower processing times for children with DLD were observed, as well as for older vs. younger children. Extended study with more emphasis on the development of the task might show better discrimination between groups.

\section{Error analyses}

Errors of participants were analysed and proportions of two types of errors, phonological and semantic, were determined.

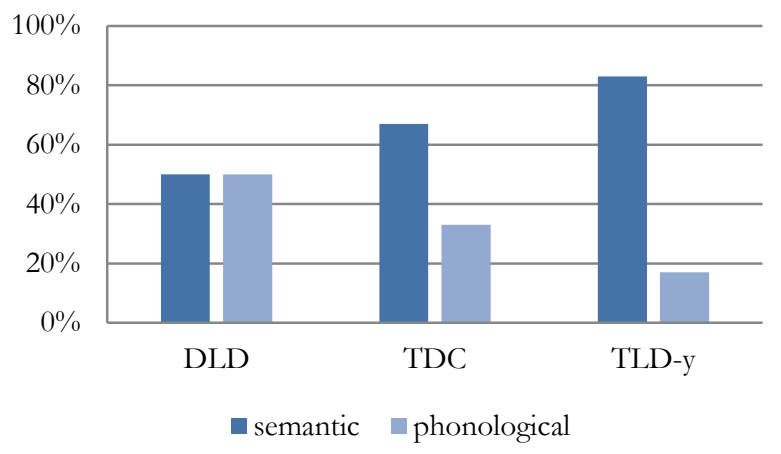

Figure 1. Error analysis - median proportion of each type of error (in total number of errors).

Difference in the proportion of errors made in picture selection task did not reach statistical significance when it comes to phonological errors $(\chi 2=1,65 ; \mathrm{df}=2 ; \mathrm{p}=0,437)$, nor when it comes to semantic errors $(\chi 2=1,65 ; \mathrm{df}=2$; $\mathrm{p}=0,438)$ between any groups of participants. However, proportion of phonological errors was highest in group of children with DLD, while proportion of semantic mistakes was highest in group of younger controls (receptive language matches). More semantic errors in youngest children can support tentative conclusion that those children may not recognize the appropriate semantic features and possibly that they are still in process of fleshing out the semantic representation of specific verbs (Pye, Loeb, Redmond, Richardson, 1995). Tendency to more phonological errors seen in DLD children could support the thesis of deficit in word's phonological properties i.e., lack of secure phonological representation to map it onto. A child with phonological difficulties finds it hard access the check (meaning of the verb) because he or she has not yet mastered the phonological skills that are required for speech development. Tendency to more phonological errors in group of DLD probably reflects broader challenges than lexical in language development of those children. Bishop (2014) emphasise that learning of tense could be impaired by problems with phonological segmentation.

Findings from this study, although only on the level of tendency, could have an important impact on clinical practice. If children with DLD make qualitatively different type of errors compared to TDC, clinical goals should take this into the consideration. Difficulties differentiating between the sounds they hear, i.e., protracted phonological issue, can lead to difficulties regarding grasping the sound in their working memory, which will make them face difficulty analysing and combining sounds, mixing phonemes, producing speech sound clusters and so on. 


\section{Limitations of the study}

This study also has several limitations that need to be stated. The limitation of this study is a small number of participants and need for the better control of verbs features (age of acquisition, imageability, lemma frequency, familiarity, word length et cetera). The testing process seems to have been too simple for all children - the target image in an environment with only two distractors makes it easier to recognize the target word, and sometimes provides greater opportunity for guessing. Some other verb recognition test methods (e.g., recognizing verbs in a sequence of pseudoverbs or close task) may be a more sensitive measure for differentiate DLD group from typical children at the age of 10. The small number of subjects and the small number of items (stimulus) along with the uncontrolled impact of speech and language therapy could have masked the differences in verb processing between the typical language development and children with DLD. Since the children with DLD were included in speech and language therapy in SUVAG Polyclinic, the obtained results might have reflected the impact of speech-language therapy, which was not the goal of this work, but it can in no way be left out, so it should be reported and controlled in future research.

\section{CONCLUSION}

The present explored differences in accuracy and reaction time, a well as in types of errors, in children with DLD and their typically developing peers matched by age (TDC) and receptive vocabulary (TDC-y). Research showed no statistically significant differences regarding these variables, which does not corroborate findings from previous research. Although there were not statistically significant differences among groups, children with DLD showed a tendency to a longer and more variable reaction time compared to TDC and TDC.y.

Besides reaction time and accuracy, types of errors were also analysed. Tendency to more phonological errors in group of DLD children compared to controls lead to a tentative conclusion that deficit in word's phonological properties could have an impact on broader lexical skills.

According to findings from this study, it seems important to emphasize phonological exercises parallel with exercises focused on vocabulary span in working with children with DLD. Also, future research could benefit from this research by taking into consideration observed tendencies and apply similar design on larger groups of participants, with more emphasis to the construction of the material. As concrete, frequent, more imageable and earlieracquired words are retrieved and processed faster (Luniewska at. al, 2016) and the frequency is the most important predictor of verb naming (Masterson, Druks, Gallienne, 2008), more variability regarding those features of verbs should be included to develop more appropriate testing material. Number of exposures to the new word in children with DLD can play a significant role in speed of processing but it can also lead to overlearning and ceiling effect affecting research outcomes. Children with DLD participated in this study were enrolled in therapy for several years. Future studies should also control this variable.
Despite limitations, results show several points which would be worthwhile to investigate more systematically in future research.

\section{REFERENCES}

1) Auer, E. T. (2009). Spoken word recognition by eye. Scandinavian Journal of Psychology, 50(5), 419-425. https://doi.org/10.1111/j.1467-9450.2009.00751.x.

2) Bastiaanse, R., Bol, G. (2001). Verb Inflection and Verb Diversity in Three Populations: Agrammatic Speakers, Normally Developing Children, and Children with Specific Language Impairment (SLI). Brain and Language. 77, 274 282. doi:10.1006/brln.2000.2401,

3) Bishop, M. V. D., Kuvač Kraljević, J., Hržica, G., Kovačević, M., Kologranić Belić, L. (2014.) Test razumijevanja gramatike - TROG-2: HR. Jastrebarsko: Naklada Slap.

4) Bishop D.V.M. (2014). Problems with tense marking in children with specific language impairment: not how but when. Philosophical Transactions of the Royal Society. B 369: 20120401. http://dx.doi.org/10.1098/rstb.2012.0401

5) Bishop, D. V. M., North, T., Donlan, C. (1996). Nonword Repetition as a Behavioural Marker for Inherited Language Impairment: Evidence From a Twin Study. Journal of Child Psychology and Psychiatry, 37(4), 391403. doi:10.1111/j.1469-7610.1996.tb01420.x

6) Bornstein, M.H., Cote, L.R., Maital S, Painter, K., Park, S-Y, Pascual, L., Vyt A. (2004). Cross-linguistic analysis of vocabulary in young children: Spanish, Dutch, French, Hebrew, Italian, Korean, and American English. Child Development. 75:1115-1139.

7) Brackenburi, T., Pye, C. (2005). Semantic Deficits in Children With Language Impairments: Issues for Clinical AssessmentLanguage, Speech, and Hearing Services in Schools. Vol. 36, 5-16. Pristupljeno 31.1.2021. Brackenbury (bgsu.edu)

8) Dockrell, J. E., Messer, D., George, R. (2001). Patterns of naming objects and actions in children with word finding difficulties. Language and Cognitive Processes, 16, 261-286.

9) Dockrell, J. E., Messer, D., George, R., Ralli, A. (2003). Beyond naming patterns in children with WFDs Definitions for nouns and verbs. Journal of Neurolinguistics, 16, 191-211.

10) Dunn, L. M., Dunn, L. M., Kovačević, M., Padovan, N., Hržica, G., Kuvač Kraljević, J., Mustapić, M., Dobravac, G., Palmović, M. (2009). Peabody slikovni test rječnika (PPVT-IIIHR). Jastrebarsko: Naklada Slap.

11) Gentner, D. (2006). Why verbs are hard to learn. In: Hirsh-Pasek, K., Golinkoff, R. (ed). Action meets word: How children learn verbs. Oxford, United Kingdom: Oxford University Press; p.544-564.

12) Hayiou-Thomas, M. E., Bishop, D. V. M., Plunkett, K. (2004). Simulating SLI: General cognitive processing stressors can produce a specific linguistic profile. Journal of Speech, Language, and Hearing Research, 47(6), 1347-1362. https://doi.org/10.1044/ 1092-4388(2004/101

13)Kail, R. (1994). A method of studying the generalized slowing hypothesis in children with specific language impairment. Journal of Speech and Hearing Research, 37, 418421. 
14) Kuvač Kraljević, J, Olujić, M. (2018). Imageability and subjective frequency of the 500 rated nouns in the Croatian Lexical Database. Suvremena lingvistika, 85, 73-89.

15) Leonard, L. B. (1998). Children with specific language impairment. Cambridge, MA: MIT Press.

16) Luniewska, M., Haman, E., Armon-Lotem, S., Etenkowski, B., Southwood, F., Anđelković, D., D., Blom, E., Boerma, T., Chiat, S., de Abreu, P. E., Gagarina, N. (2016). Ratings of age of acquisition of 299 words across 25 languages: Is there a cross-linguistic order of words? Behavior Research Methods, 48(3), 1154-1177. doi.org/10.3758/s13428-015-0636-6

17) Masterson, J., Druks, J., Gallienne, D. (2008). Object and action picture naming in three-and five-year-old children. Journal of Child Language, 35(2), 373-402. doi.org/10.1017/S0305000907008549

18) Miller, C. A., Kail, R., Leonard, L. B., Tomblin, J. B. (2003). Speed of processing in children with specific language impairment. Journal of Speech, Language, and Hearing Research, 44, 416-433.

19) Nash, M., Donaldson, M.L. (2010). Word Learning in Children with Vocabulary Deficit. Journal of Speech, Language, and Hearing Research Vol. 48 439-458.

20) Peterb, M.S, Durrantb, S, Jessopa, A., Bidgoodc, A., Pineb, J.M., Rowlanda, S.F. (2019). Does speed of processing or vocabulary size predict later language growth in toddlers? Cognitive Psichology, 115, 101 238, https://doi.org/10.1016/j.cogpsych.2019.101238

21) Pye, C., Loeb, D.F., Redmond, S., Richardson, L.Z. (1995). When do Children Acquire Verbs? In: E.V. Clark (Ed), The Proceedings of the Twenty-Six Annual Child Language Research Forum (pp 60-70). Stanford: Centre for the Study of Language and Information.

22) Rothweiler, M., Chilla, S., Clahsen, H. (2011). Subjectverb agreement in Specific Language Impairment: A study of monolingual and bilingual German-speaking children. Bilingualism: Language and Cognition, 15(01), 3957. doi:10.1017/s136672891100037x

23) Sheng, L., McGregor, K. (2010). Object and action naming in children with specific language impairment. Journal of Speech, Language, and Hearing Research, 53, 1704-1719. 24) Soares, A. P., Costa, A. S., Machado, J., Comesaña, M., Oliveira, H. M. (2017). The Minho Word Pool: Norms for imageability, concreteness, and subjective frequency for 3,800 Portuguese words. Behavior Research Methods, 49(3), 1065-1081. https://doi.org/10.3758/s13428-016-0767-4.

25) Thompson, C. K. (2003). Unaccusative verb production in agrammatic aphasia: the argument structure complexity hypothesis. Journal of Neurolinguistics, 16(2-3), 151167. doi:10.1016/s0911-6044(02)00014-3

26) Weismer. S.E., Hesketh, L.J. (1996). Lexical Learning by Children with Specific Language Impairment: Effects of Linguistic Input Presented at Various Speaking rates. Journal of Speech and Hearing Research, Volume 39, 177190. doi:10.1044/jshr.3901.177

27) Windsor, J., Kohnert, K. (2004). The search for common ground: Part I. Lexical performance by linguistically diverse learners. Journal of Speech, Language, and Hearing Research, 47, 877-890. 